\title{
REFLECTIONS ON ENGLISH AS AN ACADEMIC SUBJECT IN CHINA
}

\author{
REFLEXÕES SOBRE O INGLÊS COMO MATÉRIA ACADÊMICA NA CHINA
}

Ruan Wei ${ }^{1}$

\begin{abstract}
Resumo: Este artigo faz uma breve análise da história do inglês como matéria acadêmica na China, enfocando a importância primordial atribuída pela China ao ensino e aprendizado de línguas estrangeiras em geral e de inglês em particular. Argumenta-se que a China é provavelmente o único caso na história humana em que um imenso Estado soberano investe esforços sistemáticos e contínuos em aprender uma língua estrangeira, formulando políticas linguísticas unificadas e fazendo-as cumprir de uma maneira consistente e potente; e, ao agir assim, a China teve sucesso em tornar o mundo externo transparente e traduzido para ela em um curto espaço de tempo, integrando todos os tipos de conhecimento novo em seu sistema cognitivo, ampliando seu horizonte e transformando as mentes de sua população, efetuando deste modo uma metamorfose civilizatória generalizada.
\end{abstract}

Palavras-chave: inglês, matéria acadêmica, compulsória, metamorfose civilizatória

\begin{abstract}
This paper gives a brief examination of the history of English as an academic subject in China, focusing on the paramount importance China attaches to the teaching and learning of foreign languages in general and of English in particular. It is argued that China is probably the one and only case in human history in which an immense sovereign state puts systematic and sustained efforts into learning a foreign language, formulating unified linguistic policies and enforcing them in a consistent and potent manner; and by so doing, China has succeeded in making the external world translated and transparent to it in a short time, integrating all kinds of new knowledge into its cognitive system, broadening its horizon and transforming the minds of its population, thus effecting an overall civilizational metamorphosis.
\end{abstract}

Keywords: English, academic subject, compulsory, civilizational metamorphosis

1.

During the Opium Wars that took place in the 1840s and the 1860s, a sleepy China was defeated again and again by Western powers, with which it had to sign a series of unequal treaties. In this grave national and civilizational crisis unprecedented in history, China experienced a kind of collapse of cultural confidence. It was even seized by a great anxiety and horror about its prospect of survival, let alone faring well, in this brave new world which seemed to have imposed itself on China, or China seemed to have so suddenly and unexpectedly found

\footnotetext{
${ }^{1}$ Hunan Normal University - Changsha, Hunan, China; https://orcid.org/0000-0002-2925-6478;

2639742395@qq.com
} 
itself in. As is known, this anxiety and horror would culminate in China's defeat by Japan in the Sino-Japanese War of 1894 and would continue to haunt the nation even long afterwards. Under the circumstances, however, China began to awake. Reform initiatives were introduced and a modernization movement was launched, just to make it strong again, or 'make it great again', to borrow the words of the American President Donald Trump, led by such paramount imperial officials as Zeng Guofan, Li Hongzhang, Zuo Zongtang, Hu Linyi and somewhat later, Zhang Zhidong.

Against this background, Jingshi Tongwen Guan, or Capital College of Foreign Languages, was officially installed in 1862 in Beijing by the Qing government. ${ }^{2}$ This can reasonably be taken as the very start of English as an academic subject in China, because with the founding of the Capital College, the first department of English ever in any Chinese college or university was set up. More importantly, this can be seen as the very start of China's modern college education. As soon, following the founding of the department of English and of those of French, Russian, German and Japanese successively in the following years, the Capital College of Foreign Languages would install a department of mathematics, offering mathematical and astrological courses. This is a perfect illustration of the great importance that China then attached to the study of foreign languages in general and of English in particular. As it would turn out, this eager-to-learn attitude would produce a profound impact on China and would eventually exert intercivilizational and even geopolitical ramifications for the entire world.

In 1898, Jingshi Daxuetang or the Capital University, the predecessor of Peking University, was founded. From the very outset it first put English, French and German courses in its core curriculum, whereas subjects such as astronomy, mathematics, physics, chemistry and medicine that were non-linguistic yet commonsensically more important than language were introduced only later on. ${ }^{3}$ In 1902, The Capital University incorporated the Capital College of Foreign Languages, and the very top or the most prestigious Chinese university at the time, i.e., Peking University, was thus officially launched. In 1919, with a major structural reshuffling, thirteen departments of the university were founded, among which were quite a few departments of foreign languages and literatures, that is, those of the English Language and Literature, of the French Language and Literature and of the German Language and Literature, etc.. ${ }^{4}$ Special attention should be paid to the fact that, among all the foreign languages China has been eager to learn since the late Qing period, English always came out on top.

The above is the basic story line of the important role that English played in the founding of the very best modern Chinese university, and of the beginning of English as an academic subject in China. It was a similar situation in other major cities, as the establishment of Shanghai College of Foreign Languages (Shanghai Tongwen Guan), Guangzhou College of Foreign Languages (Guangzhou Tongwen Guan), and etc., indicates. As a matter of fact, in the 1920s and early 1930s, English programs and departments were mushrooming in the newly founded colleges and universities in many Chinese cities, not only in Shanghai and Guangzhou, but also in Tianjin, Wuhan, Nanjing, Chengdu, Changsha, Chongqing and etc.. Afterwards, for quite some time, not much progress was made in the growth of English as an academic subject, mainly because of the Anti-Japanese war from 1937 to 1945 and because of the two civil wars fought between the Nationalist Party and the Chinese Communist Party from 1927 to 1936 and in the second half of the 1940s. Yet with the founding of the People's Republic of China and the outbreak of the Korean War, as tensions increased between China and America or between China and the West as a whole, English was marginalized or even totally disappeared from the

\footnotetext{
2‘Jingshi Tongwen Guan’ (《京师同文馆》) , in Baidu Encyclopedia (《百度百科》), 2020/07/10.

36Jingshi Daxuetang' (《京师大学堂》) , in Baidu Encyclopedia (《百度百科》), 2020/07/10.

4‘Peking University’ (《北京大学》), in Baidu Encyclopedia (《百度百科》), 2020/07/11.
} 
college and school curricular in the 1950s and the 1960s, with Russian replacing it as the No. 1 second language.

Twenty years later, however, as tensions between China and America eased and the SinoAmerican relationship defrozened in the early 1970s, English began to resume its former prestigious status. With the launching of the Reform and Opening-up Movement in the late 1970s, English very soon replaced Russian as the most important second language. The real eruption of the English language, however, not only as the No. 1 foreign language but also as a compulsory academic subject for all school pupils and college students, occurred in the 1980s, when the Reform and Opening-up Movement was at full steam. Beginning in 1984, English was officially included in the national college entrance examination by the Ministry of Education, ${ }^{5}$ which would prove to be the watershed for and the most powerful booster to English's status as assuredly the Number 1 foreign language and the most important academic subject. Beginning in the early 2000s, China saw an unprecedentedly enormous expansion of higher education, which in turn effected a massive expansion of English programs, departments and schools at the universities and colleges.

According to the statistics issued by the Ministry of Education, there were 2914 highereducation institutes of various kinds by May, 2017. ${ }^{6}$ According to the statistics issued the Ministry of Education, there were 518,900 schools, colleges and universities in China in 2018, with 276 million enrolled students. ${ }^{7}$ What does this mean? Before answering this question, let us be reminded of what profound transformation Chinese economy and the lives of the Chinese people have undergone since 1978. As a matter of fact, not only has China metamorphosed, but also the entire world has changed accordingly. China's economic volume surpassed USA as early as 2014, by PPP or Purchasing Power Parallel, according to the statistics of the World Bank. China's has shown its technological and infrastructural prowess in the way of a nationwide high-speed rail network, a tremendous number of advanced and even luxurious airports, harbors, and railway stations, its $5 \mathrm{G}$ technology and engineering that stay the most advanced in the world despite Donald Trump's desperate sanctions, its Chang'e Lunar Exploration Program, its Tiangong Space Station, the building of which will have been accomplished by 2022, and etc..

Thus, in the eyes of some, here has emerged a Leviathan or a would-be superpower with an immense population, a colossal economy and advanced science and technology, ready to take over the world in which America and other Western powers have been predominating for so long. This is absolutely untrue, since China is willing to play a secondary and complementary role in the existing world order mainly created and maintained by the West and its allies, from which it has benefitted so much, and without which none of its achievements is possible. Now we are perhaps in a better position to answer the question regarding what the tremendous scale of English teaching and learning at Chinese universities and schools really means. Since there are now almost 30 millions learners of English at the college level, there must be an even larger number of English learners at the school level. As a matter of fact, in 2018, there are 57.37 million at the junior high school level, 45.27 million at the senior high school level, and 105.65

\footnotetext{
${ }^{5} \mathrm{Xu}$ Junqian, 'China now major innovator in second language learning', in China Daily, July 27-28, 2019, p. 3.

6 'The Ministry of Education issues a list of China's higher education institutes (2017)', in Website of the Central People's Government of PRC, 2020/07/11. http://www.gov.cn/fuwu/2017-06/16/content_5202888.htm

7 '518,900 schools, colleges and universities in China in 2018, with 276 million enrolled students', in China News Website, http://www.chinanews.com/sh/2019/02-26/8765085.shtml, 2020/07/12.
} 
million at the primary school level. ${ }^{8}$ Attention should be paid to an even more important fact that, for about 30 years, vigorous linguistic policies have been systematically formulated and consistently enforced by the national and provincial governments just to make English a compulsory subject at the college and high school levels, and thus a de facto compulsory subject at the primary school or even kindergarten levels.

If at the school level the most basic English — rudimentary vocabulary and grammar, and elementary listening, speaking, reading and writing skills — is taught, then at the college level English is provided to both English majors and non-English majors as a very special subject. For all non-English majors, 'College English' is compulsory and this policy is enforced nationwide, not to vary from province to province, from city to city, or from college to college. For non-English majors, a basic knowledge of British and American culture, and Western culture as a whole, is required and a basic proficiency of English in terms of listening, speaking, reading and writing skills is actively promoted, while at the same time much stress is laid on reading and ESP, or English for Special Purposes. At most universities and colleges, undergraduate non-English major have to pass two tough English examinations, that is, band-4 and band-6 tests for non-English majors, the scores of which will accompany them upon graduation and will affect their future career; whereas undergraduate English majors are required to take two equivalent examinations too, i.e., band-4 and band-8 tests for English majors. For postgraduate English majors, courses in English literature (British, American, Canadian, Australian literatures, and etc.), English-related linguistic studies, English-related translation studies, British studies, American Studies, English-related intercultural studies, English-related communication studies and English-related international relations, and etc., are offered and their graduate papers can focus on these areas.

Apart from regular schools, colleges and universities supervised by the Ministry of Education, there is an enormous number of commercial teaching institutes in the form of training schools and classes which offer English courses. Private tutoring is not to be neglected either, which boasts a huge volume in commercial teaching. One further fact (perhaps a more important fact than those just mentioned above) worth our attention is that technology has now made possible both on-line independent learning and on-line face-to-face teaching and learning. These factors combined with regular schools, colleges and universities have brought about a situation in which an estimated 300 million people of all ages are learning English in China today. ${ }^{9}$

\section{3.}

It can thus be safely assumed that, to a large portion of the present Chinese population, say, 10 to 20 million whose English proficiency level is fairly high, and 300 million who are learning English, Western knowledge in its entirety, that is, its science and technology, its philosophies, religions, political theories, history, literature and arts, let alone business and commerce, now becomes readily translated and widely accessible. In other words, Western knowledge has now become more or less transparent to China. In contrast, during the first two or three decades of the $20^{\text {th }}$ century, the very limited translatedness and transparency of Western Civilization were as yet the monopoly of a very small number of elites in coastal cities such as Shanghai, Ningbo, Fuzhou, Xiamen and Guangzhou, who had been educated at missionary schools and had thus been exposed to Western influences earlier than those in inland China. To put it simply, the enormous efforts put into English learning has made the outside world readily

\footnotetext{
8 'The number of enrolled pupils at primary and high schools in China, 2018', in Baidu Wenku, https://wenku.baidu.com/view/05fb911e3086bceb19e8b8f67c1cfad6185fe957.html, 2020/07/11.

${ }^{9} \mathrm{Xu}$ Junqian, 'China now major innovator in second language learning', in China Daily, July 27-28, 2019 , p. 3.
}

Rev. Bras. Lit. Comp. Niterói, v. 22, n. 41, pp. 110-116, set. /dez. 2020 
apprehensible to China today, which is already producing geo-economic, geo-political and geocultural consequences globally.

This is in striking contrast to the deplorable situation before the Opium War in which China was still in the dark, the external world being as yet almost totally untranslated and untransparent to it, waiting for it to awake, and to explore, to understand, and eventually to sort of feel comfortable in. In this very process, a once weak China would at last metamorphose into a world power. It is a wonder that any civilization could have been so profoundly changed in such a short time and on such a massive scale, to a great extent by means of learning English as a second language in a compulsory manner and with tremendous enthusiasm, and through absorbing and incorporating the knowledge of the outside world mostly conveyed in that language. This is absolutely astounding and can even be seen as a 'civilizational feat'. It is unprecedented in human history, and might even be the one and only case.

When ancient Greco-Roman Civilization expanded, the Greek and Latin languages, and the knowledge conveyed in them, were more or less adopted by non-Greek and non-Roman peoples who were either conquered by or allied with the conquerors. They might lose their sovereignty and, in many cases would very much lose their linguistic independence. In the case of India, although it cannot be said that it lost its linguistic independence completely when under the colonial rule of the British, it did make use of English as a de facto Lingua Franca and as a major educational and administrative language. The situation has continued right into the present even long after India became independent and the British rule officially came to an end in 1947. This is attributable not only to British colonialism, but also to the innate linguistic affinity between English and the majority of Indian languages, both of which are Indo-European, and to the fact that historically India had always lacked a Lingua Franca, or, there had always been too much linguistic diversity at the expense of the growth of a powerful unifying native language. China is a totally different story. Because of its sheer demographic and geographic size, its long history and profound culture, and its linguistic unity even before modern times with the unified system of the characters serving as a key factor unifying the very diverse languages and dialects which would otherwise have adopted a diversity of writing systems, thus endangering the prospect of the nation's linguistic unity, and with Mandarin as an undisputed Lingua Franca nationwide - China could not possibly have been overwhelmed in its encounter with the West, its sovereignty, territorial integrity and linguistic independence thus remaining intact.

It is even more astonishing if we take into account the fact that the various Chinese languages of the Sino-Tibetan language family are very remote indeed from those of the IndoEuropean language family, which includes English, French, German, etc. in it, in terms of linguistic distance; whereas the majority of languages in India that was once under British rule, and the languages of the peoples who were subdued by Greeks and Romans in ancient times, were much closer to those of the conquerors. The greater the linguistic distance, the greater difficulty one has in grasping a foreign language. In spite of the linguistic distance and of the innate linguistic difficulty it incurred, the Chinese people have managed to learn English and other European languages well enough. In fact, China is probably the one and only case in the entire history of civilization where an immense sovereign state has put systematic and sustained efforts into learning a foreign language, formulating unified linguistic policies and enforcing them in a systematic and potent manner.

By so doing, China has succeeded in making the external world very much translated, transparent and apprehensible to itself in a relatively short time, integrating all kinds of new knowledge into its cognitive system, thus actively adapting itself to the new world intellectually, culturally and psychologically while effecting an overall civilizational metamorphosis, to which our generation have been witnesses. In this very process, Chinese civilization has become 'hybridized', the minds of the Chinese people have been transformed, the possibility world of 
China as a nation has been hugely enlarged, and its intellectual horizon has thus been profoundly broadened. It is thus proper to say that China today is to a great degree bi-lingual, bi-cultural and bi-civilizational. This is in striking contrast not only to the dynastic China before 1840 when the Opium War took place, but to Western nations, which since 1840 have been mainly evolving in the same cultural direction as before, having never in any drastic way been impacted by another civilization. In retrospect, an observation can be offered that this civilizational metamorphosis and hybridization of China has undergone is hugely productive, not only making China solve the problem of national 'survival', but 'making it great again', or to be restored to its historical position where it used to able to make great economic, technological and cultural contributions to the global community. It can arguably be said that even at the present time, China is already exerting a great impact upon the world.

The translatedness of Western knowledge and relative transparency of Western Civilization to China is even more astounding if contrasted with the comparatively small number and comparatively tiny percentage of Western students at various educational levels to have taken Chinese as an important language to learn and grasp. This would mean that, to the West as a whole, China as both a civilization and a 'nation state' has been very much untransparent, or at most translucent, if not utterly incomprehensible, not only culturally, psychologically and intellectually, but in other aspects as well. Any fair and objective observer of the situation would have to admit that an average Chinese student knows so much more about the West, especially the English-speaking countries than an average Western student knows about China. Since by and large Western governments at various levels so far have not felt any considerable pressure to introduce systematic foreign languages policies, or may not even have had the awareness of the need to do so, to encourage the teaching and learning of Chinese as a second language at schools and colleges, let alone making it a compulsory task, it is predictable that no drastic change will take place in the near future. Anyone of a reasonable mind cannot fail to see that this is a deplorable situation, a situation of possible intercultural and geoeconomic, if not necessarily of geo-political, consequences.

However, things may probably not be so pessimistic. Anyhow, we have reasons to hope for the best. With the rapid progress of AI technology and the related technologies, machine translation will in the future be so much cheaper, so much more accurate, so much more powerful, and so much more accessible, that second language learning will probably be more or less obsolete in a matter of two or three decades, or at most in half a century. At least, it will probably be unnecessary for foreign language learning to be conducted in such a compulsory and consistent manner and on such a massive scale as we witnessed in the $20^{\text {th }}$-century China, and as has been happening for the past two decades of the present century in this country. If this becomes true, China will eventually be the one and only case in human history, in which an immense sovereign state puts systematic and sustained efforts into the learning of English and other foreign languages just to introduce, translate and integrate the knowledge conveyed by those languages into its own cognitive system, broadening its horizon and transforming the minds of its people, thus engendering a metamorphosis of an entire civilization. There is so much evidence that this has already been happening and will continue to be so.

\section{WORKS CITED:}

THE MINISTRY of Education issues a list of China's higher education institutes. Website of the Central People's Government of PRC, 2020/07/11. http://www.gov.cn/fuwu/201706/16/content_5202888.htm 
518,900 SCHOOLS, colleges and universities in China in 2018, with 276 million enrolled students. China News Website, http://www.chinanews.com/sh/2019/02-26/8765085.shtml, 2020/07/12.

THE NUMBER of enrolled pupils at primary and high schools in China, 2018. Baidu Wenku, https://wenku.baidu.com/view/05fb911e3086bceb19e8b8f67c1cfad6185fe957.html, 2020/07/11.

XU Junqian. China now major innovator in second language learning. China Daily, July 2728, 2019, p. 3.

Ruan Wei is Xiaoxiang Professor of Comparative Civilization and Western Studies at Hunan Normal University. For further information, please refer to:

https://fsc.hunnu.edu.cn/info/1224/3864.htm

Submetido em 13/05/2020

Aprovado em 13/06/2020 